\title{
Qualitative analysis of the supervision process and identification of constraints that occur in supervision
}

\author{
Elfi Tasrif*) \\ Universitas Negeri Padang, Indonesia \\ *)Corresponding author, $\equiv$ e-mail: elfitasrif@ft.unp.ac.id
}

\begin{abstract}
The quality of education is largely determined by good school management by supervisors for a better quality of learning, not least in Vocational High Schools. This type of research is qualitative with a case study research design. The main target of this research is supervisors of vocational schools in the Padang city. This research is limited to describing qualitatively the supervision process and identifying the constraints that occur in supervision. The data source of this research is from key informants, purposively. Data collection techniques with interview and observation techniques. Data analysis by coding, linking and, interpreting themes. The results of the research are the low professionalism of school supervisors and the low appreciation of the school supervisor profession. The conclusion is that the constraints were basically the result of improper recruitment patterns and were exacerbated by weak control mechanisms.
\end{abstract}

Keywords: Vocational high school (VHS), supervisor, supervision.

How to Cite: Tasrif, E. (2020). Qualitative analysis of the supervision process and identification of constraints that occur in supervision. COUNS-EDU: The International Journal of Counseling and Education, 5(4), 196-204. DOI: 10.23916/0020200531640

\section{Introduction}

Teachers are the key to the success of the quality of education in this country (Baehaqi, 2018). It takes creativity from a teacher in developing learning, both technology-based and optimizing existing resources in realizing the quality of vocational education learning, including in Vocational High Schools (Tasrif et al., 2020, 2021; Syah, \& Tasrif, 2021; Syahmaidi et al., 2021). Furthermore, as professionals, teachers also need supervision and guidance in order to improve the implementation of the learning process they have been doing so far (Berliani, 2017). A teacher who is considered capable of carrying out his duties with the conditions they have fulfilled before they are appointed as a teacher still needs supervision from various parties (Grant, Graham, \& Jones, 2017). From the research experience so far, the role of school supervisors, school principals, and teachers in managing education in schools has not been maximal. These problems, it can be indicated that teacher performance has not been maximized in improving their professionalism, so they need to be supported by supervisors and principals to foster, guide, train, and develop teacher abilities through academic supervision (Dibyantoro, 2017; Asakura, \& Maurer, 2018; Aini, 2019; Evanofrita, Rifma, \& Nellitawati, 2020).

But on the other hand, the academic supervision services carried out by supervisors and school principals are not in accordance with what the teachers themselves expect (Indrawati, Somantri, \& Juarsa, 2017; Hidayat, 2019). Supervisors and school principals are the only auditors who check administrative completeness without providing guidance and guidance and training to teachers (Karmila, \& Suchyadi, 2020). So that there are indications that the competence of supervisors is below expectations (Kok et al., 2018; Kervadec et al., 2019), in particular, supervisors are still considered weak in the field of academic 
supervision (Mann, \& Merced, 2018), and teachers stated that supervisors lack the skills needed to become an effective supervisor (Kaufman, Hughes, \& Riccio, 2010; Hernández-González, Inza, \& Lozano, 2016; Karomah, 2021), this condition is no exception in Vocational High Schools (Krisdayati, \& Hariyati, 2020).

Vocational High Schools (VHS) have a different learning environment and climate from schools in general (Kusumaningrum et al., 2016; Ganefri et al., 20118; Tasrif, 2019), because curriculum guidance and learning targets make VHS have to be given different treatment (Jamilah et al., 2019). Graduates from VHS in Indonesia, including in the Padang city, are required to be able to compete in the world of work and be able to survive in the community with their competencies (Hidayat, 2015; Hidayat, 2017b; Hidayat et al., 2020). Besides that, through the competencies possessed by VHS graduates, they must be able to develop themselves to be able to become entrepreneurs (Ganefri et al., 2017; Hidayat, 2017a; Hidayat et al., 2018a; Ganefri et al., 2020), and open employment opportunities (Hidayat, \& Yuliana, 2018). But in reality, based on data from the Central Statistics Agency as of February 2021, the graduates of Vocational High School (VHS) are still the highest compared to graduates of other education levels, namely 11.45 percent. This is very unfortunate considering that VHS graduates are prepared to be ready to work and become entrepreneurs, but empirical data shows the opposite, namely that the majority of VHS graduates are unemployed (Yulastri, \& Hidayat, 2017; Hidayat et al., 2018b; Yulastri et al., 2018; Hidayat, 2017). et al., 2019a, 2019b, 2019c). One of the factors causing this problem to occur is the weak implementation of academic supervision carried out by supervisors at VHS (Tasrif, 2019).

The quite heavy task that this education supervisor should carry out will have implications for improving the quality of the world of education. The theoretical study, which is accompanied by comparisons with facts in the field and carried out through a preliminary study of Vocational High Schools in the Padang city, shows unsatisfactory facts. Based on observations, it shows that in general the arrival of supervisors at VHS is limited to formal visits to the principal and elements of school leadership, although sometimes class visits are also carried out but even then it is carried out only in passing. Initial surveys show that the current supervision process is still unsatisfactory, this is reflected in empirical data about the process of supervision that is carried out carelessly (Masful, 2017), it even seems that it is just fulfilling the obligation to come to school (Messi, Sari, \& Murniyati, 2018). Another fact shows that every teacher should teach with preparation and enthusiasm, but in fact, many come and just spend the lesson hours, this situation cannot be found quickly by supervisors (Mette et al., 2017; Pallawagau, Prihatin, \& Suminar, 2017; Paul, Roy, \& Roy-Chowdhury, 2018; Christmas, 2019).

This apprehensive condition based on the results of the Directorate of Manpower's research also shows the weak coordination between supervisors and school principals, resulting in sub-optimal supervision (Rahmiyati, 2019; Putra, 2021; Rahayu, 2021). The unprofessionalism of school supervisors in optimizing their role in schools can be caused by a number of factors (Rahabav, 2016). The ability of supervisors towards the 6 competencies required by government regulations has proven to be disappointing and needs immediate improvement, as can be seen in Figure 1.

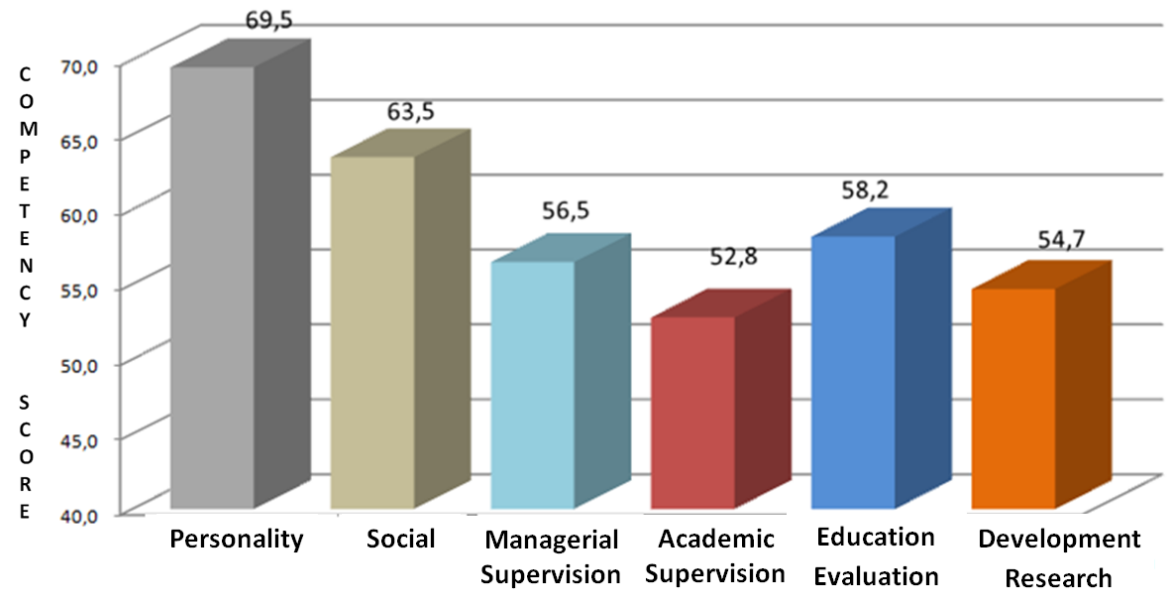

Figure 1. Mastery of School Supervisor Competencies (Source: Directorate of Education Personnel (2009)) 
Based on Figure 1, shows that the score of mastery of personality competencies (69.5), social competence (63.5), managerial supervision competence (56.5), academic supervision competence (52.8), educational evaluation competence (58.2), and research development competencies (54.7). On the other hand, the role of education supervisors, especially for vocational high schools, is not only limited to "supervising" but should be more of supervision (Riyanto, 2017; Ruskala, 2021). So from the descriptive data on the mastery of the competence of school supervisors, it is very clear that during the supervision process there are several obstacles. This condition becomes very interesting for further study and investigation. Furthermore, from the previous explanation, it is very important to conduct research on the supervision process and identify the constraints that occur in supervision.

\section{Method}

This research is qualitative research designed in the form of case study research (Pranita, Kurniah, \& Suprapti, 2018; Marohong, 2020). The research subjects of SMK supervisors in the Padang city are described in a qualitative descriptive form. This research is limited to describing qualitatively the process of supervision and identification of the obstacles that occur in the supervision of Vocational High Schools in Padang City. The data source of this research consisted of the main sources, namely two vocational school supervisors (P1 and P2). In addition, to enrich information and to cross-check or triangulate data, two stakeholders from the elements of teachers and school principals (S1 and S2) were used. Determination of the sources was done purposively. Data collection techniques using interview and observation techniques. Furthermore, data analysis performed by collecting data, coding, linking themes, and interpreting themes. The code used is a combination of letters and numbers, for example, WMD1P1 where $\mathrm{W}=$ interview, MD = Informant code (in this study there were four informants, namely $\mathrm{MD}, \mathrm{MJ}, \mathrm{DM}$, and $\mathrm{FZ}$ ), $\mathrm{P}=$ Supervisor, $\mathrm{S}=$ Stakeholder, while the numeric code ( $1,2,3$ and so on) denotes 'the process to ...'

\section{Results and Discussions}

The results of the research on the supervision process and the obstacles that occur in the supervision of Vocational High Schools in the Padang city are obtained from the results of interviews, participant observation results, and document study results.

\section{Results of Interview}

The supervision process that is intended is to observe the supervision process carried out in relation to the professionalism of school supervisors. The review is more focused on academic supervision and the obstacles encountered. The results of the interview with P1 when asked about the target schools that must be served by the supervisor stated that each supervisor served 3 schools on average for managerial supervision, while for academic supervision according to the rules the ratio was 40 teachers for one supervisor, thus the supervisor had to find additional teachers in other schools outside the 3 schools that are his responsibility, for this on average it will involve 7 other VHS for the academic supervision. The confirmation made on $\mathrm{P} 2$ also stated the same thing regarding the responsibilities of each supervisor.

This shows that the supervisor feels more conditioned as a managerial supervisor for the 3 target schools, rather than as an academic supervisor who has to foster 7 schools which is actually also his responsibility. The meaning that can be put forward is that visits are generally more of managerial supervision, while academic supervision is relatively neglected because of the plurality of fields of study in each school visited. Confirmation made to P2 was done by asking questions about filling out the supervision instrumentation form, $\mathrm{P} 2$ stated,

(... filling out forms is a labor of menial labor and is very trivial. I just made it part-time in a meeting, then I emailed it to schools. Then I just have to instruct the school to fill it out and when necessary take it to the Education Office (supervisor's office), right? It is not difficult, if the filling in of these forms is done one by one for each school, how long it will take three days to not finish.

Therefore we must be smart in dealing with technology ... that is why to become a supervisor, outstanding teachers are needed, principals who excel and also have a certificate of supervision, and not just enter- WMJ2P2) 
Perception P2 can be interpreted as the implementation of academic supervision is carried out carelessly and apprehensively. This perception at the same time strengthens the prevailing opinion that the arrival of a supervisor is just a matter of asking for a signature, or simply to fulfill the supervisor's personal interests, not as a coaching visit. Another meaning that can also be taken from P2's statement is that due to the far distribution of schools and teachers, supervisors take shortcuts without wanting to be busy having to visit directly to schools. Further perceptions from P1 and P2 regarding the implementation of academic supervision in schools for which they are responsible, P1 stated,

(Supervisors come to school without confirmation, in the early days of supervision there was a global schedule without any stipulated visiting days, which obviously worked at least twice a month. It could be that for different weeks the visit was made on different days. This attitude was taken so that the teacher who was found also varied, not the same teacher.

7 schools ... 40 teachers ... it's just that sometimes in one year the implementation did not have the opportunity to finish the 40 teachers

Through clinical supervision, through interviews to find out the weaknesses of the teacher concerned, then find solutions. There is also something that is done using an instrument approach, namely by looking at the teacher's teaching tools, then we set their scores by referring to the standard process, after which we are given input on how it should beWMD2P1).

The results of the interviews presented were compiled from the three topics put forward by P1. The first topic was related to the pattern of P1 visits to schools which were carried out suddenly without any confirmation to stakeholders, this was intended so that the teachers met were varied. While the second topic is related to the distribution of teachers in a plot that is distributed across a number of schools, so that the process of supervision, especially coaching in academic supervision, is difficult to do optimally. Even in one year, sometimes the coaching of the 40 teachers is not fulfilled. The third topic expressed by P1 is related to the pattern of implementation in coaching. P1 tries to apply various patterns of approaches to teachers.

The confirmation was made to $\mathrm{P} 2$ regarding the three topics revealed by P1, basically, P2 also did the same thing. Regarding school visits, P2 also makes impromptu visits or unscheduled visits. As for the third topic, the same thing was also responded to directly by P2's opinion which stated that it was difficult to complete the coaching of the 40 teachers.

The triangulation carried out on S1 and S2 is found to support what was previously stated. Perception of S1 states, "... supervisors just come to visit, look around then fill in the data that he has visited the school .. then just leave .. yes, just ask for an autograph" (WDMS1). Meanwhile, S2 has the perception that "... if the supervisor comes to school it will not add value to the teacher or school" (WFZS2).

\section{Results of Participant Observation}

The results of the observations made on the supervision process are basically the same in principle as what the informants say. Observation is carried out by placing the researcher himself as a passive participant, that is, by participating in the field or school just observing. Apart from that, informally the researchers also visited the VHS and then engaged in informal conversations with teachers and school principals.

The results obtained indicate that the implementation of supervision is carried out randomly, without adequate preparation, so that supervisors themselves find it difficult to define whether they are currently or will be carrying out academic supervision or managerial supervision. The results of the observations also looked at the actions of supervisors who acted more as interrogators than as supervisors. Supervisors are more likely to monitor than motivators. The pattern of coaching that is carried out is not serious. This attitude appears in the opinion of researchers as a result of supervisors not preparing and planning what will be done properly, so the important thing is to do "something" as a supervisor. Even more worrying is the existence of schools or areas of expertise, which are rarely visited by supervisors because the supervisors are not managerial supervisors in the area of expertise. 


\section{Results of Document Study}

The results of the review of supervisory documents, especially regarding the implementation process of academic supervision, show that the supervisory documents presented in P1 and P2 are relatively adequate. This completeness is viewed from the aspect of adequacy, however, the main document needed cannot be shown, namely the document regarding the annual work plan or semester of the supervisor in carrying out the task. Supervisors have documents such as performance appraisal instrument forms, teacher competency assessment forms, learning tools completeness forms as well as assessment reports and monitoring results reports, but they do not have structured planning when it will be implemented.

\section{Discussion on the Supervision Process and Constraints that Occur in Supervision}

The supervision process includes a number of aspects which are essentially a professional assistance process, as a control so that each planned element runs according to the agreed or established standards (Triastuti, 2017). Kaufman (2010) states that supervision in the scope of education is a process of developing and maintaining professional competence and school functions. Supervision is a collaborative process between supervisors and teachers and principals (Stacey et al., 2017; Saleh, 2019; Sitaasih, 2020;), which is carried out on an ongoing basis (Sukayana, Yudana, \& Divayana, 2019). This collaboration is primarily aimed at the growth and enhancement of school, academic and managerial abilities, so that through the supervision process, program continuity and development can take place well (Tsui et al., 2017; Wartabone, 2021).

The results of the study actually show the low professionalism of school supervisors and the low appreciation of the school supervisor profession, of course, this becomes an obstacle in improving the quality of academic supervision. Other findings also show that it is very difficult for supervisors to distinguish between the academic supervision process and the managerial supervision process. This is a complication caused by a number of factors that have been recorded, such as (1) Supervisors do not understand or care about academic supervision or managerial supervision; (2) The supervisor is working without a good work program, or the program may exist but is invalid; (3) Motivation of supervisors is low; (4) There are too many school variants; (5) Weak control mechanism; (6) The report is not substantially analyzed by the education office; (7) Supervisor visits are carried out as if without a plan, the pattern of guidance is not optimal; (8) The distribution of supervisors is not evenly distributed so that supervisors force themselves to foster teachers who are not their respective fields. The eight points put forward show low commitment and a lack of seriousness on duty.

Another obstacle found in supervision is those related to competency demands that must be met (Zepeda, \& Ponticell, 2018), as stated in the Supervisory Workbook and in the Supervisory Quality Standards book (Zulfikar, \& Ibrahim, 2017: Zulfiani, Thaha, \& Mahmud, 2021). Supervisors must also be more intense in mobilizing the activities of the School Supervisory Work Meeting, as a forum to increase their professionalism. However, all of this is closely related to the 'row material' of the supervisors themselves, as long as recruitment is not addressed, this will remain a stumbling block in mobilizing supervisors and supervisors (Zuchowski, 2016). The solution offered in addressing the problem of supervisor recruitment (a special case at the Padang City Education Office) is the need for a breakthrough or renewal of the supervisor recruitment pattern. Recruitment is carried out based on a position auction pattern, each supervisory candidate who meets the stipulated requirements and requirements is required to go through a special 'auction' session such as the presentation of the vision, mission, and testing or supervision simulation. The vision, mission stated is a contract that will be accounted for each year. For supervisors who fail to fulfill the contract, they are willing to accept the consequences laid down against them.

\section{Conclusions}

The process of supervision, especially academic supervision, takes place in conditions that are not favorable or not in accordance with the standards set by government regulations, especially in relation to a number of constraints such as the low ability of supervisors and also the low professionalism of supervisors. The professionalism of school supervisors is low, resulting in low appreciation of the supervisory profession. The constraints that occurred were basically the result of improper recruitment patterns and were exacerbated by weak control mechanisms. 


\section{References}

Aini, N. (2019). Implementasi Supervisi Kepala Sekolah Terhadap Guru di Sekolah Menengah Kejuruan Farmasi Samarinda. Tarbiyah Wa Ta'lim: Jurnal Penelitian Pendidikan dan Pembelajaran, 6(3), 170-178.

Asakura, K., \& Maurer, K. (2018). Attending to social justice in clinical social work: Supervision as a pedagogical space. Clinical Social Work Journal, 46(4), 289-297.

Baehaqi, M. A. (2018). Manajemen Supervisi Akademik Kepala Sekolah dalam Meningkatakan Kinerja Guru (Studi Deskriptif Kualitatif di Smk Bandung Barat 2 Cihampelas dan Smk IT NU Saguling). Syntax Literate; Jurnal Ilmiah Indonesia, 3(8), 51-60.

Berliani, T. (2017). Implementasi Supervisi oleh Kepala Sekolah dalam Meningkatkan Profesionalisme Guru. JMSP (Jurnal Manajemen dan Supervisi Pendidikan), 1(3), 218-226.

Dibyantoro, S. S. (2017). Manajemen Supervisi Akademik untuk Meningkatkan Kinerja Guru Mata Pelajaran Pendidikan Jasmani dan Kesehatan SMK Di Kecamatan Sewon Kabupaten Bantul. utile: Jurnal Kependidikan, 3(2), 126-137.

Evanofrita, E., Rifma, R., \& Nellitawati, N. (2020). Pelaksanaan Supervisi Akademik Kepala Sekolah Di Sekolah Luar Biasa. JMKSP (Jurnal Manajemen, Kepemimpinan, dan Supervisi Pendidikan), 5(2), $217-$ 229.

Ganefri, Hidayat, H., Kusumaningrum, I., \& Mardin, A. (2017). Needs Analysis of Entrepreneurship Pedagogy of Technology and Vocational Education with Production Based Learning Approach in Higher Education. International Journal of Advanced Science, Engineering and Information Technology, 7, 1701-1707. http://dx.doi.org/10.18517/ijaseit.7.5.1510

Ganefri, G., Hidayat, H., Yulastri, A., Mardin, A., Sriwahyuni, D., \& Zoni, A. A. (2018). Perangkat Pembelajaran Pedagogi Entrepreneurship Dengan Pendekatan Pembelajaran Berbasis Produk di Pendidikan Vokasi. In Prosiding Seminar Nasional \& Internasional, 1(1).

Ganefri, G., Hidayat, H., Yulastri, A., \& Ifdil, I. (2020). Need analysis of the production based entrepreneurship training model: learning entrepreneurship in higher education. COUNS-EDU: The International Journal of Counseling and Education, 5(2), 58-63.

Grant, B., Graham, A., \& Jones, J. (2017). 'Guidelines for discussion': a tool for managing postgraduate supervision. In Quality in postgraduate education (pp. 165-177). Routledge.

Hernández-González, J., Inza, I., \& Lozano, J. A. (2016). Weak supervision and other non-standard classification problems: a taxonomy. Pattern Recognition Letters, 69, 49-55.

Hidayat, S. (2019). Upaya Peningkatan Penguasaan Teknologi Guru SMK Negeri Darang dan Melalui Supervisi Akademik Multi Metode. Syntax Literate; Jurnal Ilmiah Indonesia, 4(8), 143-153.

Hidayat, H. (2015). Production based Learning: An Instructional Design Model in the context of vocational education and training (VET). Procedia-Social and Behavioral Sciences, 204, 206-211.

Hidayat, H. (2017a). How is the Application and Design of a Product-Based Entrepreneurship Learning Tools in Vocational Higher Education?. In International Conference on Technology and Vocational Teachers (ICTVT 2017) (pp. 223-228). Atlantis Press.

Hidayat, H. (2017b). Impact of learning with the production-based learning model in vocational school. International Journal of Research in Engineering and Social Sciences, 7(2), 1-6.

Hidayat, H., Herawati, S., Tamin, B. Y., \& Syahmaidi, E. (2018). How is the practicality of technopreneurship Scientific learning model design in vocational higher education?. International Journal of Scientific Research and Management, 6(09).

Hidayat, H., Herawati, S., Syahmaidi, E., Hidayati, A., \& Ardi, Z. (2018). Designing of technopreneurship scientific learning framework in vocational-based higher education in Indonesia. International Journal of Engineering and Technology (UAE), 7(4), 123-127.

Hidayat, H., \& Yuliana. (2018). The Influence of Entrepreneurship Education and Family Background on Students' Entrepreneurial Interest in Nutritious Traditional Food Start Ups in Indonesia. International Journal of Engineering and Technology(UAE). 7(4), 118-122. https://doi.org/10.14419/ijet.v7i4.9.20631

Hidayat, H., Tamin, B. Y., Herawati, S., Khairul, K., \& Syahmaidi, E. (2019a). The contribution of technopreneurship scientific learning and learning readiness towards the entrepreneurship learning outcomes in higher vocational education. Jurnal Pendidikan Vokasi, 9(1), 21-32.

Hidayat, H., Ardi, Z., Yuliana, \& Herawati, S. (2019b ). Exploration of the need analysis for technopreneurship scientific learning models in higher vocational education. International Journal of Economics and Business Research, 18(3), 356-368.

Hidayat, H., Tamin, B.Y., Herawati, S., Hidayati, A., Muji, A.P. (2019c). Implementation of technopreneurship scientific learning for produce electronic product prototypes in engineering 
education. International Journal of Innovative Technology and Exploring Engineering, 8(11), 28422846. http://dx.doi.org/10.35940/ijitee.K2406.0981119

Hidayat, H., Tamin, B. Y., Herawati, S., Ardi, Z., \& Muji, A. P. (2020). The Contribution of Internal Locus of Control and Self-Concept to Career Maturity in Engineering Education. Int. J. Adv. Sci. Eng. Inf. Technol, 10(6), 2282-2289.

Indrawati, E., Somantri, M., \& Juarsa, O. (2017). Implementasi Supervisi Akademik di SMP. Manajer Pendidikan, 11(5).

Jamilah, Y., Sukardi, S., Tasrif, E., Nendra, F., \& Firdianis, E. (2019). Evaluation Program of Work Practice in Industrial Vocational High School (Seen From Respondents Teacher Supervisor). International Journal of Educational Dynamics, 2(1), 180-187.

Karmila, N., \& Suchyadi, Y. (2020). Supervisi Pendidikan Di Sekolah Alam Bogor. Jurnal Pendidikan dan Pengajaran Guru Sekolah Dasar (JPPGuseda), 3(1), 31-33.

Karomah, N. (2021). Peningkatan Mutu Mengajar Guru Produktif Melalui Supervisi Akademik Ketua Program Keahlian. Jurnal Ilmiah Pro Guru, 7(2), 189-196.

Kaufman, J., Hughes,T.L., \& Riccio, C.A. (2010). Hand book of education, training, and supervision of school psychologists in school and community, Volume II. New York: Routledge Taylor \& Francis Group.

Kervadec, H., Dolz, J., Tang, M., Granger, E., Boykov, Y., \& Ayed, I. B. (2019). Constrained-CNN losses for weakly supervised segmentation. Medical image analysis, 54, 88-99.

Kok, M. C., Vallières, F., Tulloch, O., Kumar, M. B., Kea, A. Z., Karuga, R., ... \& Taegtmeyer, M. (2018). Does supportive supervision enhance community health worker motivation? A mixedmethods study in four African countries. Health policy and planning, 33(9), 988-998.

Krisdayati, F., \& Hariyati, N. (2020). Evaluasi Supervisi Akademik Dalam Pembelajaran Berbasis Teaching Factory Pada Program Keahlian Perbankan di SMK Negeri 1 Jombang. Inspirasi Manajemen Pendidikan, 8(2).

Kusumaningrum, I., Hidayat, H., Ganefri, Anori, S. \& Dewy, MS. (2016). Learning Outcomes in Vocational Education: a Business Plan Development by Production-Based Learning Model Approach. International Journal of Environmental and Science Education, 11, 1191711930.https://files.eric.ed.gov/fulltext/EJ1122558.pdf

Mann, S. T., \& Merced, M. (2018). Preparing for entry-level practice in supervision. Professional Psychology: Research and Practice, $49(1), 98$.

Marhawati, B. (2020). Pelaksanaan Supervisi Akademik Kepala Sekolah Dasar: Studi Kualitatif. JMSP (Jurnal Manajemen dan Supervisi Pendidikan), 4(2), 71-76.

Masful, M. (2017). Teknik Supervisi Pembelajaran Model ICC Berbasis Karakter Dalam Meningkatkan Kompetensi Guru SMK di Kabupaten Pasuruan Semester Ganjil Tahun Pelajaran 2016/2017. JDMP (Jurnal Dinamika Manajemen Pendidikan), 2(1), 71-81.

Messi, M., Sari, W. A., \& Murniyati, M. (2018). Pelaksanaan supervisi akademik pengawas sekolah sebagai upaya peningkatan profesionalisme guru. JMKSP (Jurnal Manajemen, Kepemimpinan, dan Supervisi Pendidikan), 3(1), 114-125.

Mette, I. M., Range, B. G., Anderson, J., Hvidston, D. J., Nieuwenhuizen, L., \& Doty, J. (2017). The wicked problem of the intersection between supervision and evaluation. International Electronic Journal of Elementary Education, 9(3), 709-724.

Miftahudin, S., Amin, M. M., \& Sukmawati, S. Pelaksanaan Supervisi Akademik Dalam Upaya Meningkatkan Kinerja Guru Di SMK N 1 MEMPAWAH HILIR. Jurnal Pendidikan Dan Pembelajaran Khatulistiwa, 8(3).

Natal, A. (2019). Peningkatan Kompetensi Guru Dalam Proses Pembelajaran Melalui Pelaksanaan Supervisi Akademis DI SMK SWASTA MUHAMMADIYAH PASIR PENYU. Jurnal Pendidikan Tambusai, 3(1), 439-447.

Pallawagau, M., Prihatin, T., \& Suminar, T. (2017). Pengembangan Model Supervisi Akademik dengan Mentoring Method dalam Pembelajaran yang Mendidik Pada SMK di Kabupaten Kupang. Educational Management, 6(1), 9-19.

Paul, S., Roy, S., \& Roy-Chowdhury, A. K. (2018). W-talc: Weakly-supervised temporal activity localization and classification. In Proceedings of the European Conference on Computer Vision (ECCV) (pp. 563-579). 
Pranita, U., Kurniah, N., \& Suprapti, A. (2018). Pelaksanaan Supervisi Klinis Kepala Sekolah Pendidikan Anak Usia Dini Islam Terpadu Kota Bengkulu (Studi Deskriptif Kualitatif di PAUD IT Auladuna Kota Bengkulu). Jurnal Ilmiah Potensia, 3(1), 54-65.

Pront, L., Gillham, D., \& Schuwirth, L. W. (2016). Competencies to enable learning- focused clinical supervision: a thematic analysis of the literature. Medical education, 50(4), 485-495.

Putra, H. J. (2021). Hasil Supervisi Mutu Pendidikan pada Sekolah Model SMK Negeri 1 Pujut Tahun 2020. Jurnal Paedagogy, 8(2), 169-180.

Rahabav, P. (2016). The Effectiveness of Academic Supervision for Teachers. Journal of Education and Practice, 7(9), 47-55.

Rahayu, S. W. (2021). Peran Kepala Sekolah Dalam Menumbuhkan Semangat Supervisi Para Pendidik Baru Sebagai Alternatif Memajukan Kualitas Pendidikan. JAMP: Jurnal Administrasi dan Manajemen Pendidikan, 3(4), 352-358.

Rahmiyati, S. (2019). Pemanfaatan Aplikasi Google Form dalam Meningkatkan Pelaksanaan Supervisi Pendidikan Pengawas Madrasah. Jurnal Pendidikan Madrasah, 4(2), 201-209.

Ratner, A., Bach, S. H., Ehrenberg, H., Fries, J., Wu, S., \& Ré, C. (2020). Snorkel: Rapid training data creation with weak supervision. The VLDB Journal, 29(2), 709-730.

Riyanto, R. (2017). Pengelolaan Supervisi Pembelajaran Berbasis Kurikulum 2013 di SMK. Manajemen Pendidikan, 12(3), 217-227.

Ruskala, A. R. (2021). Supervisi Akademik Dalam Bidang Multimedia Pembelajaran Guru Di SMK YPC TASIKMALAYA. Jurnal Abdi Ilmu, 13(2), 159-174.

Saleh, D. (2019). Supervisi Akademik Dapat Meningkatkan Kualitas Pembelajaran Produk Kreatif Kewirausahaan di SMK NEGERI 1 CIMAHI. Jurnal Ilmiah P2M STKIP Siliwangi, 6(2), 90-96.

Sitaasih, D. K. (2020). Supervisi Akademik untuk Meningkatkan Kompetensi Guru Dalam Proses Pembelajaran di SD. Jurnal Ilmiah Sekolah Dasar, 4(2), 241-247.

Stacey, G., Aubeeluck, A., Cook, G., \& Dutta, S. (2017). A case study exploring the experience of resilience-based clinical supervision and its influence on care towards self and others among student nurses. International Practice Development Journal, 7(2).

Sukayana, I. W., Yudana, M., \& Divayana, D. G. H. (2019). Kontribusi Kepemimpinan Transformasional, Supervisi Akademik Kepala Sekolah, Kompetensi Pedagogik dan Motivasi Kerja Terhadap Kinerja Guru di SMK Kertha Wisata Denpasar. Jurnal Administrasi Pendidikan Indonesia, 10(2), 157-162.

Syah, A., \& Tasrif, E. (2021). Adriansyah Sistem Pembelajaran Berbasis Teknologi Informasi Dan Komunikasi "Studi Kasus MAS TI Canduang dengan Menggunakan Media Pembelajaran Google Classroom". JAVIT: Jurnal Vokasi Informatika, 10-15.

Syahmaidi, E., Hidayat, H., Hartanto, S., \& Rahmadani, A. F. (2021, February). Designing E-Training Computer Assisted Instruction Used to Pedagogic Competency in Vocational Education. In Journal of Physics: Conference Series (Vol. 1779, No. 1, p. 012038). IOP Publishing.

Tasrif, E. (2019). Academic Supervision Mechanism by Vocational High School Supervisor. In 5th UPI International Conference on Technical and Vocational Education and Training (ICTVET 2018) (pp. 160-164). Atlantis Press.

Tasrif, E., Kurnia, H., Pahtoni, T. Y., Kurniadi, D., \& Hadi, A. (2020). Analysis of Development Needs of Foster Parents Communication Media in Supporting Improvement of Academic Achievement of Students with Weak Socio-Economic Background. In The 1st Progress in Science and Technology Research Symposium. Redwhite Press.

Tasrif, E., Saputra, H. K., Kurniadi, D., Hidayat, H., \& Mubai, A. (2021). Designing Website-Based Scholarship Management Application for Teaching of Analytical Hierarchy Process (AHP) in Decision Support Systems (DSS) Subjects. International Journal of Interactive Mobile Technologies, 16(9).

Triastuti, R. (2017). Pengaruh Kompensasi, Gaya Kepemimpinan Kepala Sekolah, Supervisi Pendidikan, dan Budaya Organisasi Terhadap Kepuasan Kerja Guru di SMK Palebon Semarang (Doctoral dissertation, Universitas Negeri Semarang).

Tsui, M. S., O’Donoghue, K., Boddy, J., \& Pak, C. M. (2017). From supervision to organisational learning: A typology to integrate supervision, mentorship, consultation and coaching. British Journal of Social Work, 47(8), 2406-2420.

Wartabone, Z. (2021). Peningkatan Keterampilan Dasar Mengajar Bagi Guru Smk Negeri 1 Sindue Tobata Melalui Supervisi Klinis. Jurnal Ilmiah Pro Guru, 7(2), 168-178. 
Yulastri, A., \& Hidayat, H. (2017). Developing an Entrepreneurship Module by Using Product-Based Learning Approach in Vocational Education. International Journal of Environmental and Science Education, 12(5), 1097-1109.

Yulastri, A., Hidayat, H., Ganefri, G., Edya, F., \& Islami, S. (2018). Learning outcomes with the application of product based entrepreneurship module in vocational higher education. Jurnal Pendidikan Vokasi, 8(2), 120-131.

Yulastri, A., Hidayat, H., Ganefri, Ayu, R., \& Ardi, Z. (2019). An Empirical Study on The Effects of Pedagogy Learning Tools Entrepreneurship With Product-Based Learning Approach, Learning Readiness, and Locus of Control: A Case From Engineering Education in Indonesia. International Journal of Scientific \& Technology Research, 8(9), 1722-1727.

Zarkasi, T. (2018). Supervisi Pendidikan Bebasis ICT (Supervisi Berbasis Internet). At-Tadbir: Jurnal Manajemen Pendidikan Islam, 2(1), 17-25.

Zepeda, S. J., \& Ponticell, J. A. (Eds.). (2018). The Wiley handbook of educational supervision. John Wiley \& Sons.

Zuchowski, I. (2016). Getting to know the context: The complexities of providing off-site supervision in social work practice learning. The British Journal of Social Work, 46(2), 409-426.

Zulfiani, Z., Thaha, H., \& Mahmud, H. (2021). Model Supervisi Akademik Dalam Meningkatkan Kinerja Guru. Kelola: Journal of Islamic Education Management, 6(1), 25-36.

Zulfikar, Y., \& Ibrahim, S. (2017). Supervisi Akademik oleh Kepala Sekolah dalam Meningkatkan Kompetensi Profesional Guru SD Negeri 2 Calang Kabupaten Aceh Jaya. Jurnal Administrasi Pendidikan: Program Pascasarjana Unsyiah, 5(3). 